\title{
Ultrastructural and Histochemical Changes in Glyphosate-Tolerant Soybean Leaves Exposed to Glyphosate
}

\author{
Nayane C. P. Bomfim ${ }^{1}$, Márcio S. Silva ${ }^{1}$, Liliane S. Camargos ${ }^{1} \&$ Aline R. Martins ${ }^{1}$ \\ ${ }^{1}$ Faculdade de Engenharia de Ilha Solteira, Universidade Estadual Paulista, São Paulo, Brazil \\ Correspondence: Aline R. Martins, Faculdade de Engenharia de Ilha Solteira, Universidade Estadual Paulista, \\ São Paulo, Brazil. Tel: 55-(18)-3743-1969. E-mail: aline.botanica@gmail.com
}

Received: August 12, 2019

doi:10.5539/jas.v11n18p243
Accepted: October 11, $2019 \quad$ Online Published: November 15, 2019

URL: https://doi.org/10.5539/jas.v11n18p243

\begin{abstract}
Is it transgenic soy, resistant to glyphosate, does not suffer any injury or stress in contact with this herbicide? Anatomic studies of plant tissue are necessary to answer this question. This study investigated the influence of glyphosate in glyphosate-resistant soybean plants by analysis of leaf ultrastructure and histochemistry in a morphophysiological context. The experiment was carried out in a greenhouse, using RR soybean seeds (Glycine $\max$ (L.) Merrill, cultivar BRS Valiosa) in pots containing vermiculite and washed sand (1:1). Between the phenological stages $\mathrm{V}_{2}$ and $\mathrm{V}_{4}$, two treatments with glyphosate [N-(fosfonometil) glicina] were sprayed once a week: recommended dose $\left(5.0 \mathrm{mg}\right.$ ae plant $\left.{ }^{-1}\right)$ and control $\left(0.0 \mathrm{mg}\right.$ ae plant $\left.\mathrm{t}^{-1}\right)$, with four repetitions each. Samples of midrib and internervural area of the leaves were fixed, dehydrated in ethyl series and blocks were sectioned at a 5-10 $\mu \mathrm{m}$ thickness. The material was stained with toluidine blue $0.05 \%$ and blades mounted on "Entellan". Glyphosate decreased the thickness of the adaxial epidermis, palisade parenchyma, spongy parenchyma and total thickness of the leaf. Although, the diameter of companion cell was decreased with herbicide treatment, the diameter of the vase element increased, also increasing the size of the vascular bundle. Ultrastructural and histochemical changes caused by glyphosate can extend dysfunctions in the metabolic apparatus and plant relationship with the environment, given the inter-relation between tissue structure and its functions.
\end{abstract}

Keywords: epidermis, foliar injury, parenchyma, plant morphophysiology, vascular bundle

\section{Introduction}

Brazil is the second largest producer of soybeans (Glycine max) in the world accounting for more than $30 \%$ of world grain production. Soybean is an essential component for animal feeding with increasing use in food for humans according to National Supply Company (CONAB, 2016) and United States Department of Agriculture (USDA, 2017).

In 2016, 185.1 million ha were cultivated with genetically modified plants (GM) crops worldwide (De Vos \& Swanenburg, 2018). Brazil takes the $2^{\text {nd }}$ place in the world ranking with 49.1 million ha of GM crops planted, behind the United States (72.92 million ha) with 49.1 million ha of planted GM crops accounting for $27 \%$ of the world's arable land (International Service for the Acquisition of Agri-biotech Applications [ISAAA], 2017). There are 32.69 million hectare of transgenic soybeans, with 12.43 million hectares being cultivated with herbicide resistant cultivars, $36.7 \%$ (ISAAA, 2017).

The weeds limit soybean growth and development potential, decreasing plant productivity and grain quality (Hock, Knezevic, Martin, \& Lindquist, 2005; Knezevic, Evans, \& Mainz, 2003). The flagship for weed management is the chemical control with glyphosate, a post-emergence, systemic, broad-spectrum action herbicide used for annual and perennial weeds (Castle et al., 2004; Franz, Mao, \& Sikorski, 1997). Glyphosate acts specifically by inhibiting enzyme 5 -enolpiruvilchiquimate 3 -phosphate synthase (EPSPs), which blocks the synthesis of the essential aromatic amino acids, namely phenylalanine, tyrosine and tryptophan (Duke, Rimando, Pace, Reddy, \& Smeda, 2003).

Glyphosate is an isopropylamine salt of N-(phosphonomethyl)-glycine, an aminophosphonate analogue to the natural amino acid glycine, which therefore occupies its place in the protein synthesis. This herbicide is non-selective with low toxicity to animals, allowing deployment in rotation crops, such as corn, soybean, bean, enabling its use in large-scale in Brazilian agricultural system (Figueiredo, Silva, Boaretto, \& Ribeirinho, 2011). 
Advances in biotechnology have included the development of GM soybean cultivars, such as Glyphosate-resistant soybean (GR soybean), obtained by insertion of a gene (aroA:CP4) from bacterium Agrobacterium sp. strain CP4, which confers to these plants tolerance to glyphosate, allowing the use with recognized efficacy and broad spectrum of weed control in the soybean culture (Padgette et al., 1995; Dvoranen, Oliveira, Constantin, Cavalieri, \& Blainski, 2008). Under treatment with glyphosate, GR soybean is not affected, because of a route deviation of the shikimic acid pathway by an alternative EPSPs enzyme not-inhibited by glyphosate. Thus, this technology optimizes the integrated-weed management (Santos et al., 2007).

In a review study by Martinez and Graham (2018), it identifies some deleterious effects of glyphosate in relation to GR cultures, such as: the glyphosate compromises the shikimic acid pathway, strongly decreasing the physiological defenses GR some cultivars, despite the glyphosate tolerance, making it weaker and more vulnerable to pathogenic attack; glyphosate-based herbicide may interfere with local microbial ecology: increase the population and/or virulence of some phytopathogenic microbial species; and reducing nutrient uptake by crops has the potential to further impair disease resistance. Martinez and Graham (2018), also points out that the above deleterious effects can occur in synergism, increasing and intensifying each other's negative consequences.

Despite its great economic importance, studies are scarce on morphophysiological and histochemical aspects of the species. Metcalfe and Chalk (1950) investigated several anatomical characteristics of the family and genus, referring to Glycine max by describing the disposition of vascular bundles of petiole and Fisher (1967) described the paranervural parenchyma in the mesophyll. Anatomical studies were conducted regarding variations in leaf thickness and stomatal frequency with factors such as gas exchange rate (Dornhoff \& Shibles, 1976), water stress (Vidal \& Pognonec, 1984), different nitrogen concentrations and irradiance levels (Sims, Seemann, \& Luo, 1998).

Injury to plants may not present macroscopic symptoms, which justifies the microscopic analysis of plant tissue as a tool for early diagnosis of biotic or abiotic stresses (Tuffi Santos et al., 2008). Therefore, research on anatomical changes of the vascular bundle of leaf midrib of GR soybean subjected to glyphosate treatment is important since the use of this herbicide is common to the culture. It is also important to check whether these potential changes occur or not in the vascular tissue and how the plant responds to the changes. Thus, this study aims to understand the morphophysiological responses of GR soybean to glyphosate.

This study evaluated the influence of glyphosate in GR soybean through the analysis of ultrastructure and histochemistry in a foliar morphophysiological context.

\section{Materials and Methods}

The experiment was carried out in a greenhouse, with temperature control at $27{ }^{\circ} \mathrm{C}$, without photoperiod control, at the Laboratório de Fisiologia e Metabolismo Vegetal of UNESP, Campus Ilha Solteira, SP. The experiment was carried out in a completely randomized design, with two treatments, using commercially available RR soybean seeds, cultivar BRS Valiosa. For each treatment, it was prepared 40 pots containing 2 plants per pot. Soybean seeds, after germination, were transferred to $4 \mathrm{~L}$ pots containing vermiculite and washed sand (1:1), where they were inoculated with Bradyrhizobium sp. obtained from maceration of nodules of pre-existing soybean plants. After effective nodulation, the plants received $100 \mathrm{~mL}$ of nutrient solution without nitrogen, according to Hoagland and Arnon (1950).

The two treatments were: with $5.0 \mathrm{mg}$ ae plant ${ }^{-1}$ glyphosate, (recommended dose: $720 \mathrm{~g} \mathrm{ha}^{-1}$, acid equivalent, according to Ludwig et al., 2011), (Roundup Ready ${ }^{\circledR}$ Monsanto Company, St Louis, MO, www.monsanto.com) and, without glyphosate, $0.0 \mathrm{mg}$ ae plant $^{-1}$. The herbicide treatment was sprayed by means of a manual water sprayer, once a week between the vegetative stages $V_{2}$ (with second node and with fully developed trifoliate first leaf) and $\mathrm{V}_{4}$ (with fourth node and with fully developed third trifoliate leaf) (Fehr, Caviness, Burmood, \& Pennington, 1971).

The source of the herbicide used was Roundup ${ }^{\circledR}$, whose formulation corresponds to the following composition: $\mathrm{N}$-(phosphonomethyl) glycine isopropylamine salt $480 \mathrm{~g} \mathrm{~L}^{-1}\left(48 \% \mathrm{~m} \mathrm{v}^{-1}\right)$, $\mathrm{N}$-(phosphonomethyl) glycine (glyphosate) $360 \mathrm{~g} \mathrm{~L}^{-1}\left(36 \% \mathrm{~m} \mathrm{v}^{-1}\right)$, inert ingredients of $684 \mathrm{~g} \mathrm{~L}^{-1}\left(68 \% \mathrm{~m}^{-1}\right)$.

After the period of 15-21 days, sufficient for the metabolization of the herbicide, completely expanded leaves were sampled and fixed in FAA 50 (Johansen, 1940) for anatomical analysis.

After 48 hours the material was stored in $70 \%$ alcohol. In the completely expanded leaf, the middle region of the leaf was analyzed at the midrib and internervural areas. The samples were dehydrated in ethylic series, included in hydroxy-ethyl-methacrylate (Leica Historesin) and the blocks were cut at 5-10 $\mu \mathrm{m}$ thick. The material was 
stained with toluidine blue $0.05 \%$ in phosphate buffer and citric acid with pH between 4.5 and 6.0 (Sakai, 1973). The slides were mounted with synthetic resin "Entellan".

For the study of single cells composing the xylem and phloem, we used tissue maceration technique in which the samples were treated with "Jeffrey solution", a mixture of acids (10\% chromic acid and $10 \%$ nitric acid, 1:1), to allow the dissolution of the middle lamella and isolation of the structures (Johansen, 1940), then the samples were stained, dehydrated and assembled in glycerin gelatin.

With the obtained lamina set, photomicrographs were performed in a trinocular microscope, with cross section. These images were submitted to image analysis using the program Image Tool 3.0, which allowed the measurement in micrometers $(\mu \mathrm{m})$ of the epidermis thickness (abaxial and adaxial); parenchyma (palisade and spongy), vascular bundle and total leaf thickness. The diameter $(\mu \mathrm{m})$ of the companion cells, sieve tube elements, vessel elements and fibers were measured. To measure the diameter of the vessel elements (xylem) of the central rib region, two metaxylem vessel elements were chosen, the two largest and most centralized. From tissue maceration, we can measure the length $(\mu \mathrm{m})$ of vessel elements (short and elongated), fibers (short and elongated) and vascular bundle.

Histochemical tests were performed in fresh material, hydrated, fixed, and included in histological resin. To detect lipid substances, we used Sudan IV (Jensen, 1962); for starch, iodized zinc chloride (Strasburger, 1913); for phenolic compounds, ferric chloride (Johansen, 1940) and for pectic substances, Ruthenium red (Johansen, 1940). To check the natural aspect of the organ, we assembled the cuts of the material only in water, that is, without treatment and observed them under a light microscope.

All data were submitted to analysis of variance. The means of the treatments were compared by the Tukey test at $5 \%$ probability. Statistical analysis was performed using the software packages commercially available SISVAR ${ }^{(F e r r e i r a, ~ 2011) . ~}$

\section{Results}

Studies on anatomical characterization of plants subjected to glyphosate are scarce. However, the anatomical analysis in GR soybean allows characterizing and observing some changes. Regarding characterization of leaves of GR soybean, the mesophyll is dorsiventral with two layers of palisade parenchyma cells and four to five layers of spongy parenchyma cells (Figure 1) and the latter has sizes that vary significantly with intercellular spaces.

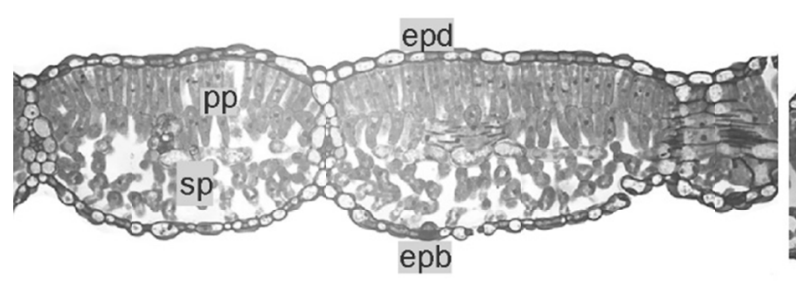

$100 \mu \mathrm{m}$

A $\quad \underline{100 \mu m}$
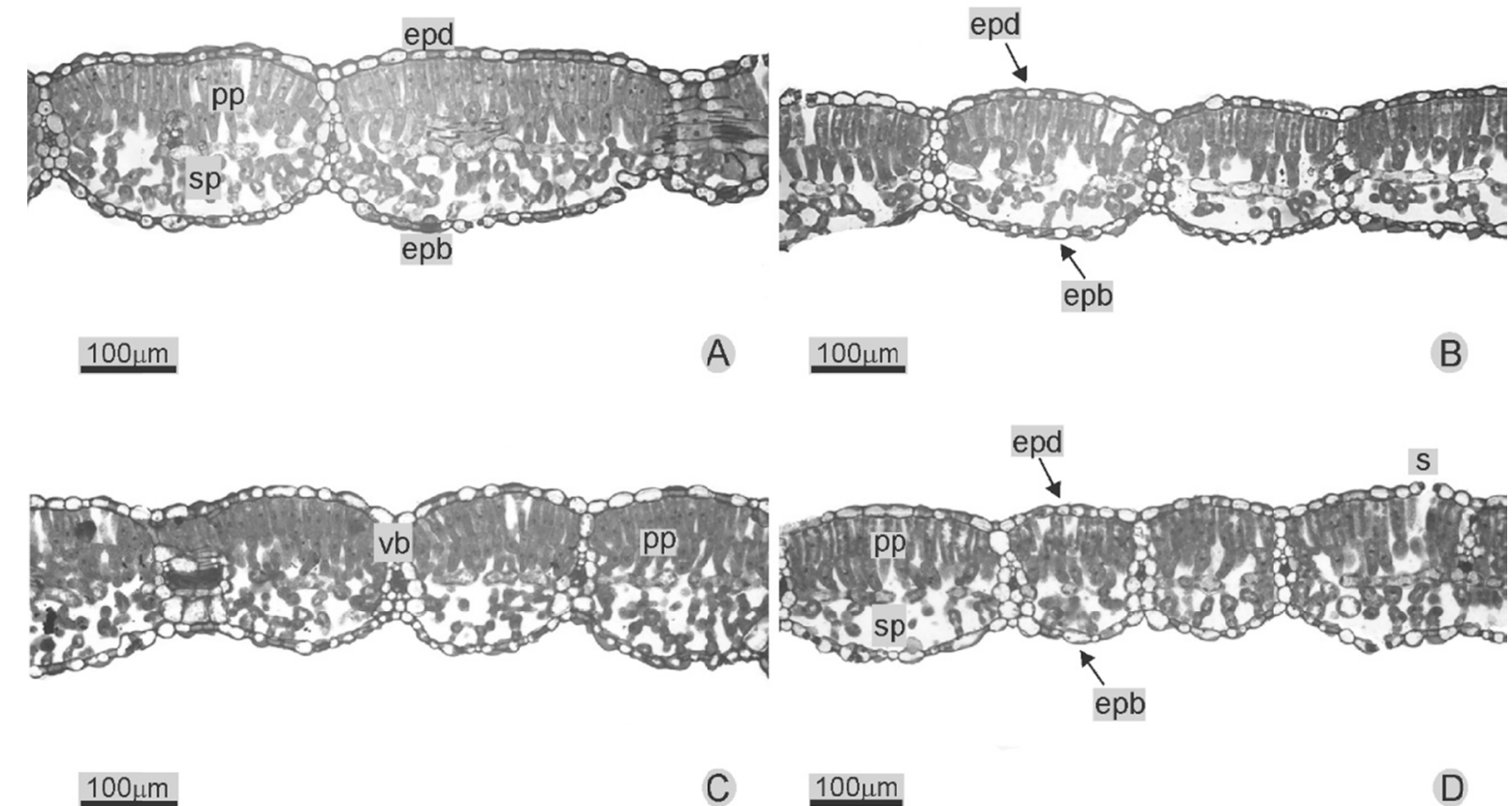

Figure 1. Photomicrographs of glyphosate-resistant soybean (Glycine max) leaves treated with glyphosate (C, D) and control samples (A, B) in cross-section. Midrib (A, C) and internervural area (B, D); pp: palisade parenchyma; sp: spongy parenchyma; epd: adaxial epidermis; epb: abaxial epidermis; vb: vascular bundle; s: stomata 
The epidermis is unisseriate with elliptical circular contour on both sides, displaying fine leaf cuticle (Figure 1A, $1 \mathrm{~B}$ and 1D). Stomata are present on both leaf sides (Figure 1D); therefore, the leaf receives the classification of amphistomatic.

In this experiment, in both foliar portions studied, it was identified decrease in structure thickness (Figures 1 and 2). In the internervural area, glyphosate decreased the thickness of palisade parenchyma (Figure 2D). In the midrib portion, thickness was decreased in adaxial epidermis, palisade parenchyma, spongy parenchyma (Figure 2A, 2C and 2D) and total leaf due to the treatment used (Figure 3).
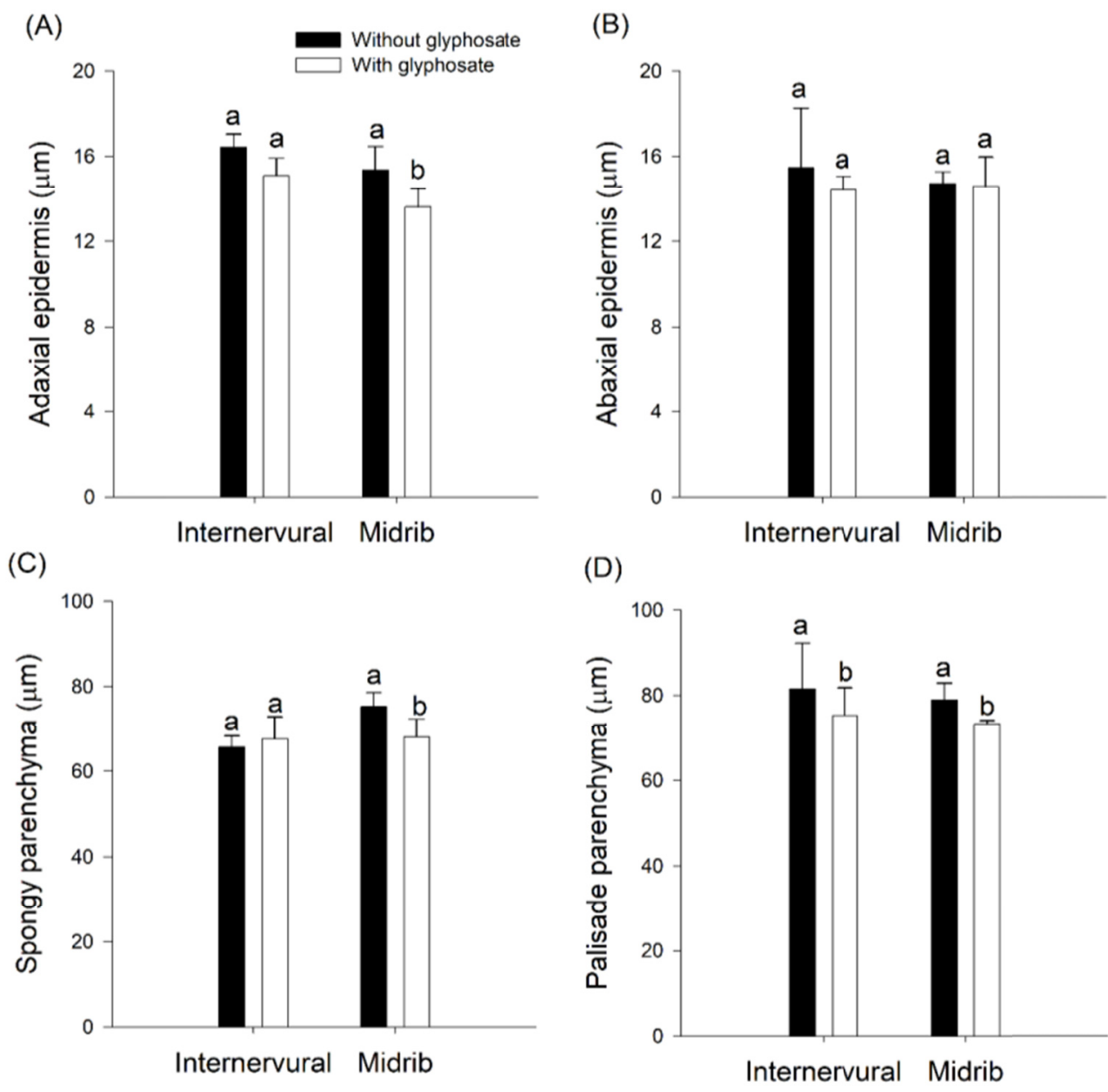

Figure 2. Abaxial epidermis thickness (A), adaxial epidermis thickness (B), spongy parenchyma thickness (C) and palisade parenchyma thickness (D) of internervural area and midrib of glyphosate-resistant soybean (Glycine $\max$ ) leaves treated with glyphosate. Values followed by the same letter in the column do not differ from each other by the Tukey test at $5 \%$ probability; $n=48$ 


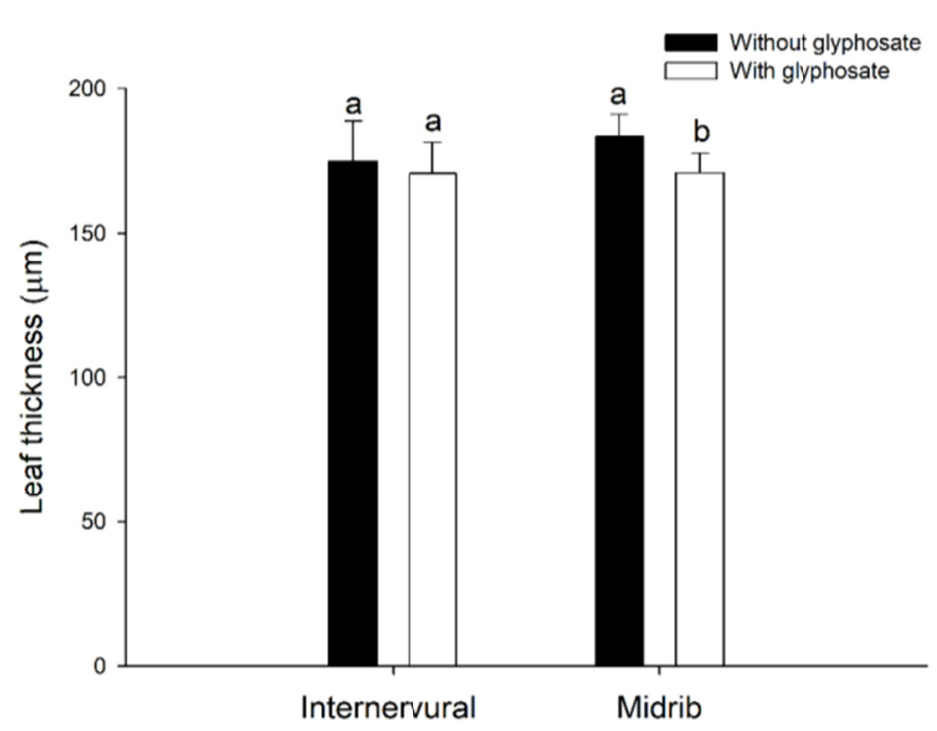

Figure 3. Leaf thickness of internervural area and midrib of glyphosate-resistant soybean (Glycine max) leaves treated with glyphosate. Values followed by the same letter in the column do not differ from each other by the Tukey test at $5 \%$ probability; $\mathrm{n}=48$

There was no change in thickness of the midrib vascular bundle between the treatments; however, the height of the vascular bundle increased when treated with glyphosate (Figures 4, 6A and 6B). There was a significant decrease in diameter of the companion cells when treated with glyphosate; nevertheless, there was no change in diameter of sieve tube elements and fibers in the presence of glyphosate in GR soybean leaves (Figures 4D, 4C, 4E, 5C and 5D). In this study, there was an increase in the diameter of the vessel elements (Figure 4F, 5C and $5 \mathrm{D})$. 


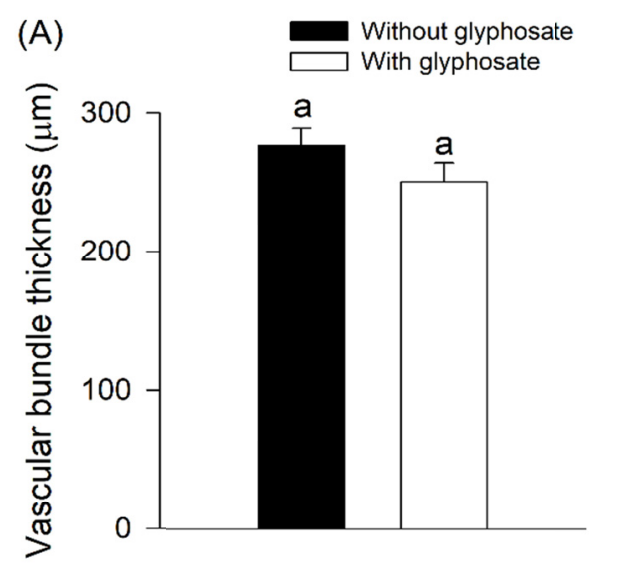

\section{(B)}

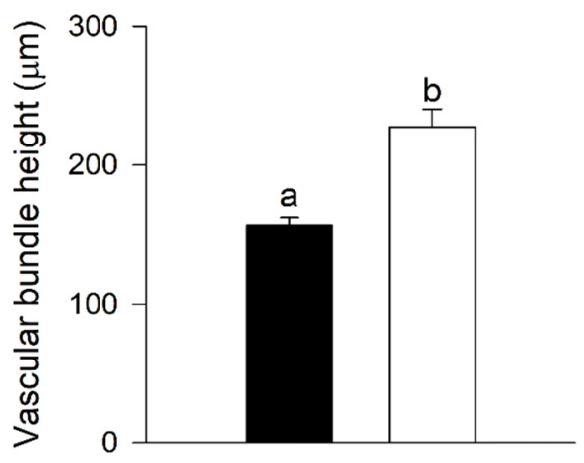

(C)

(D)

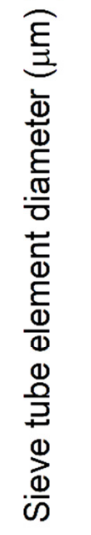

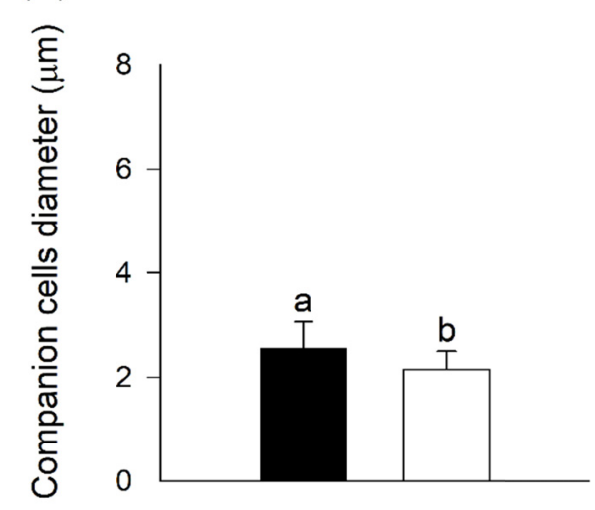

(E)

(F)
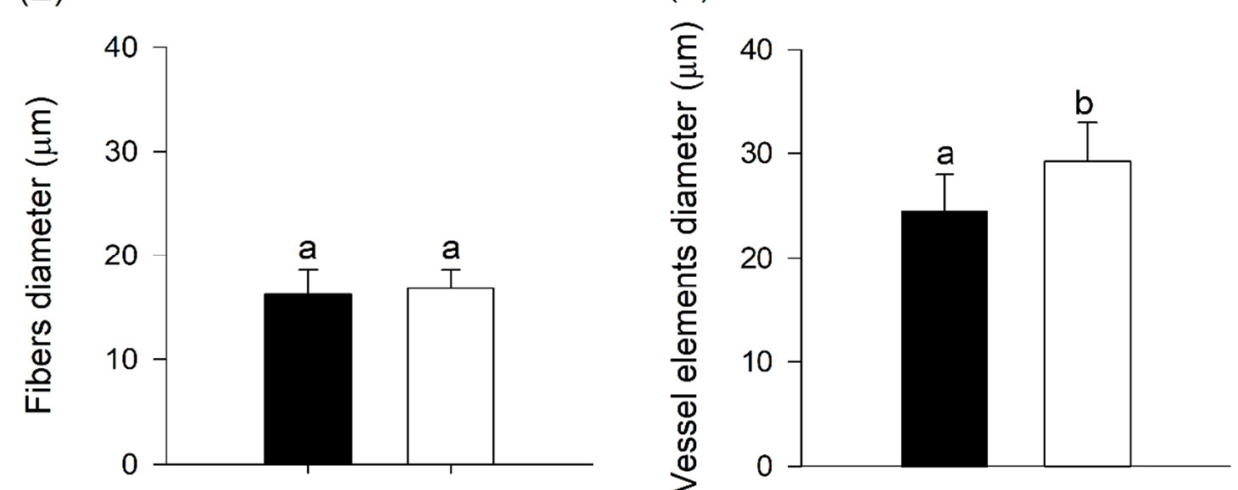

Figure 4. Vascular bundle thickness (A), vascular bundle height (B), sieve tube element diameter (C), companion cells diameter (D) fibers diameter (E) and vessel elements diameter (F) of internervural and nervural regions of glyphosate-resistant soybean (Glycine max) leaves treated with glyphosate. Values followed by the same letter in the column do not differ from each other by the Tukey test at $5 \%$ probability; $n=16$

Figure 5 shows elongate fibers (E and F) and short fibers $(\mathrm{G}-\mathrm{H})$ in the coupled material of the midrib of GR soybeans. It was possible to identify and measure the length $(\mu \mathrm{m})$ of some structures that compose the vascular bundle of midrib: two types of cells support, short (sclereids) and elongated (libriforms), and two types of the xylem vessel elements: shorter and elongated elements (Figure 5I, 5J, 5K and 5L). It was measured 24 cells of each type (fibers and vessel elements) for the control and treatment with glyphosate and we verified no statistical significant variation in the length of these cells, between the treatments (Figure 6). 


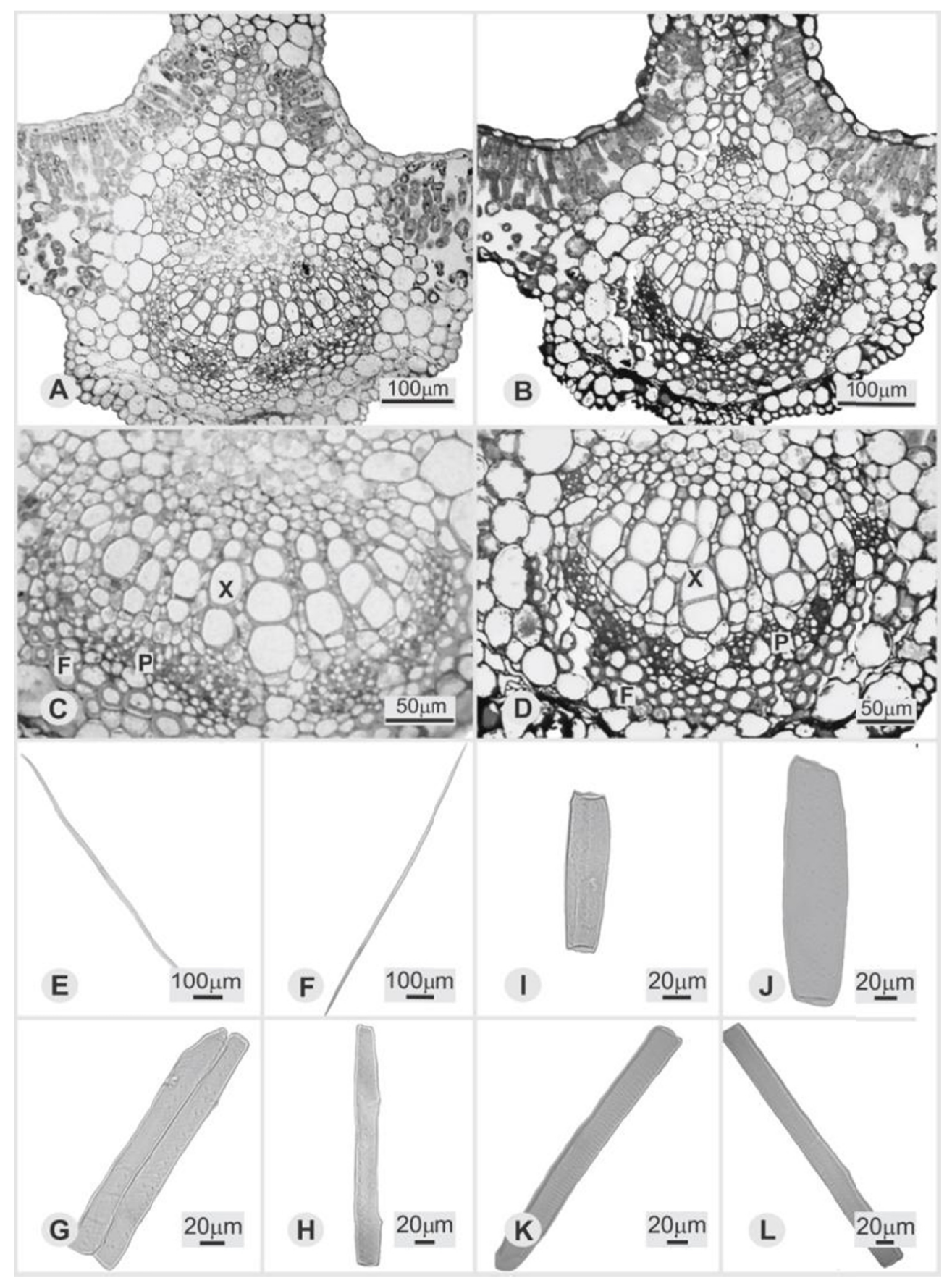

Figure 5. Cross-section of soybean leaves (Glycine max). (A, E, G, I, K) control samples and (B, D, F, H, J, L) glyphosate-resistant treated with glyphosate. (C, D) Vascular tissue of midrib leaf. Elongate fibers (E, F), short fibers (G, H,), short vessel elements (I, J), elongate vessel elements (K, L). F: phloem;

$\mathrm{P}$ : companion cells; X: metaxylem 

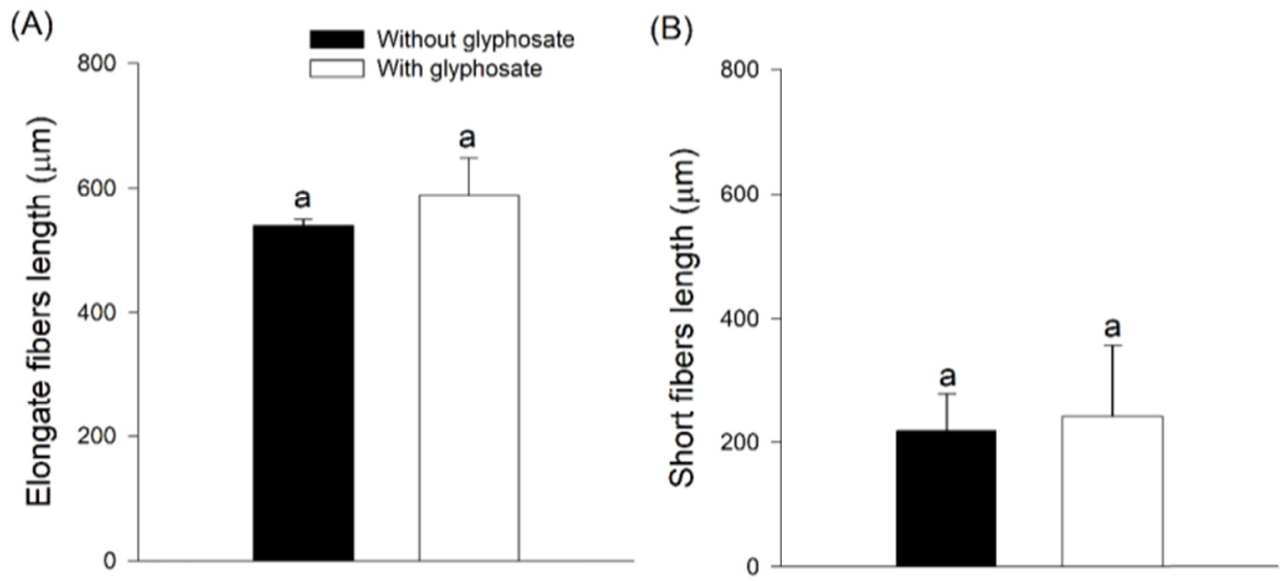

(C)

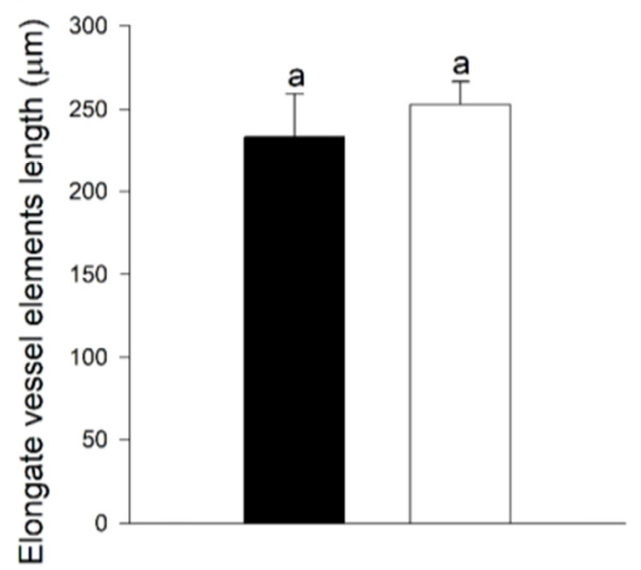

(D)

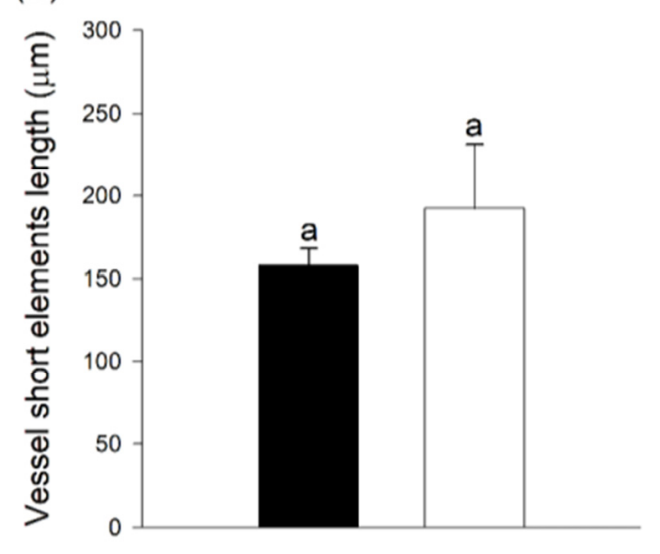

Figure 6. Average length of vascular tissue cells of internervural and midrib of glyphosate-resistant soybean (Glycine max) leaves treated with glyphosate. Elongate fibers length (A), short fibers length (B), elongate vessel elements length (C) and vessel short elements length (D). Values followed by the same letter in the column do not differ from each other by the Tukey test at $5 \%$ probability; $n=12$

There is evidence of phenolic compounds (test with ferric chloride) in different regions of the vascular bundle as well as in the palisade parenchyma, in both treatments (Table 1). The test with iodized zinc chloride showed great starch grains in leaves of GR soybean, found in the palisade and spongy parenchyma and in the vascular bundle, for both treatments (Table 1). In the palisade parenchyma, there is greater occurrence of starch grains with the presence of phenolic compounds in the mesophyll.

Table 1. Histochemical test of soybean (Glycine $\max$ (L.) Merrill) leaves treated with glyphosate

\begin{tabular}{llc}
\hline \multirow{2}{*}{ Compounds } & \multicolumn{2}{c}{ Treatments } \\
\cline { 2 - 3 } & Without glyphosate & With glyphosate \\
\hline Phenols & + & + \\
Starch & + & + \\
Lipids & + & + \\
Pectin & + & - \\
\hline
\end{tabular}

Note. ${ }^{(+)}$: Positive reaction; ${ }^{(-)}$: Negative reaction.

The cuticle, that covers the entire surface of the leaf epidermis, showed positive response to lipid (Sudan IV test) in both treatments (Table 1). Pectin substances, between polysaccharides of plant cell wall, are the ones with greater importance in the water retention process. However, after testing with ruthenium red, pectin substances 
were not observed in plants treated with glyphosate. These substances have been found only in control plants, in the epidermis, collenchyma, midrib and phloem (Table 1).

In this study, we observed that GR soybean features some level of sensitivity to glyphosate, due to microbiometric changes of most structures evaluated (Figures 2, 3 and 4).

\section{Discussion}

The tolerance mechanism conferred to the plant is not so efficient, since some ultrastructural changes have been found in GM soybeans, although the tolerance gene ( $\operatorname{aro} A)$ does not affect its final production. The pathway deviation caused by transgene aims to keep the shikimic acid pathway, which is inhibited by specific action of glyphosate on enzyme EPSPS (Jaworski, 1972; Zablotowicz \& Reddy, 2004). The shikimic acid pathway is directly responsible for the synthesis of amino acids, but there is no change in the amino acid concentration in GR soybean exposed to glyphosate (Bomfim et al., 2017).

According to Zobiole, Oliveira Junior, Constantin, and Biffe (2011), the action mechanism of glyphosate is well defined by the literature; however, some direct and indirect effects on plants that can affect important processes such as plant growth are poorly studied.

The epidermis thickness decrease in the leaf implies greater vulnerability of the plant to the attack of plant pathogens (Tuffi Santos et al., 2005 and 2007). The epidermis is one of the first barriers against phytopathogens, according to Durbin (1988), which, along with wax quantity and quality, have a structural defense mechanism that occurs even before the phytopathogenic fungus infection.

Tuffi Santos et al. (2009) also reported changes in thickness of spongy parenchyma, palisade parenchyma and foliar blade, in addition to the death of epidermal cells in eucalyptus subjected to simulated drift with glyphosate. Although the case cited concerns non-GM plants, and glyphosate cause ultrastructural damages in leaves of GR soybean as observed this work. Still, it seems that the inserted gene in plants provides resilient mechanisms due glyphosate does not affect growth, productivity and yield of GR soybeans (Bomfim et al., 2017; Silva et al., 2018).

The decrease of cell wall thickness, palisade and spongy parenchyma, may negatively affect the photosynthetic efficiency of plants (Zobiole et al., 2010), since chloroplast is aplenty in these cells, which may justify the decrease in chlorophyll concentration in GR soybean leaves exposed to glyphosate observed by Bomfim et al. (2017). In addition, parenchyma cells may show some characteristics that reflect the performance of some key activities in the plant as reserve, transportation, secretion, excretion of substances (Appezzato-da-Glória \& Carmello-Guerreiro, 2006).

According to Tuffi Santos et al. (2008), the palisade parenchyma is coupled to leaf protection against high luminous intensity. Plants suffer light saturation under excessive amount of solar radiation, decreasing efficiency of radiation use (D. Adams \& W. Adams, 1992) and compromising productivity (Casaroli et al., 2007).

Little is known about the influence of glyphosate on the vascular tissue of GR soybean leaves. Despite glyphosate resistant, under certain conditions, GR soybean presented injuries to herbicide applications associated with the formulation used (Cerdeira, Gazziero, Duke, Matallo, \& Spadotto, 2007). Several authors, such as Baas (1982), Baas and Schweingruber (1987), Carlquist (2001), Alves and Angyalossy-Alfonso (2000), report that environmental factors affect dimensions and even the arrangement of vascular elements.

Melo et al. (2007) state that in Paspalum paniculatum, under water deficiency conditions, there is no variation in the vascular bundle thickness both in leaves and roots; however, there is a decrease in the diameter of the elements of metaxylem. Stoyanova et al. (2002) observed no significant differences in water deficit effect and soil flooding that influence thickness of vascular bundles in maize leaves.

Castro et al. (2005) stated that when the plant is subjected to stress, the decrease of vessels can ensure increased transportation. Therefore, diameter reduction of metaxylem is a common response in plants subjected to stress conditions, especially considering water deficiency and can encourage water flow in the plant, according to Passioura (1982).

Appezzato-da-Glória and Carmello-Guerreiro (2006) reported that fibers are support cells, responsible for rigidity of vascular tissues. They have elongated shapes and tapered ends, with higher dimension in the longitudinal axis. The fiber walls vary in thickness; however, they are generally thicker than walls of the other cells in the secondary xylem. Shorter fibers can also be called sclereids.

According to Digby and Wareing (1966), indole acetic acid (IAA) is an important factor in establishing the diameter of the vessel elements in Robinia pseudacacia, a tree from the Fabaceae family. IAA promotes 
elongation of cambial derivatives on the formation of xylem vessels and fiber elements, and the application of gibberellins (GA) promotes fiber elongation. According to these authors, glyphosate may cause a fast decrease in IAA and GA content in plants by changing the xylem or phloematic tissue formation as evidenced in this study. On the other hand, GR soybean responds differently to the herbicide, not necessarily characterizing a negative effect to plant, but perhaps by modulating the response of plant hormone. Bomfim et al. (2017) observed the same for other metabolism aspects, in which glyphosate does not influence negatively growth and metabolism of GR soybean.

Histochemical tests play an important role in the identification and characterization of plant anatomy (Martins \& Appezzato-da-Glória, 2006), which have long been used to identify the compounds present and their occurrence in plant tissues (Sant'Ana-Santos et al., 2006; M. Santos, Freitas, Aroucha, \& A. Santos, 2009).

According to Santos et al. (2009), phenolic compounds are heterogeneous groups of substances in almost all plants, in vacuoles, cytoplasm or impregnated to cell wall. Such compounds are related to plant protection in terms of draining, animal attack, among others, despite questions regarding its functions. Souto and Oliveira (2005) stated that phenolic compounds are considered a type of chemical defense against herbivory.

Starch is one of the main reserve compounds in plants. Throughout evolution, starch has been used not only as a reserve for the plant itself, but also, as one of the most important energy sources to subsequent levels of the food chain in the ecosystems (Zeeman, S. Smith, \& A. Smith, 2004). Therefore, various organs acquired the ability to produce enzymes that degrade starch with subsequent release of glucose to be used in energetic metabolism. In plant cells, starch is stored in the form of water-insoluble granules located in special organelles (Amaral, Gaspar, Costa, Aidar, \& Buckeridge, 2007).

In analysis of the histochemical tests, relative differences were observed only for the presence of pectic substances, which may be related to the increase of the ethylene synthesis. Abu-Irmaileh et al. (1979) found that in bean, there was an increase in ethylene concentration in glyphosate-treated plants (Yamada \& Castro, 2007). Although the role of ethylene in defense responses to pathogens is widely recognized, recent studies on Arabidopsis and crop species highlight an emerging role for ethylene in regulating growth and yield of organs under abiotic stress (Dubois, Van Den Broeck, \& Inzé, 2018).

Abiotic stress conditions, which trigger the ethylene synthesis, include submersion, heat, shadow, exposure to heavy metals and high salt content, low nutrient availability and water deficiency (Skirycz et al., 2011; Thao et al., 2015; Zhang, Smith, Harberd, \& Jiang, 2016; Dubois, Claeys, Van Den Broeck, \& Inzé, 2017). In young leaves, plants exposed to environmental stress, ethylene regulates cell growth inhibition, influencing both cell division as well as its expansion (Skirycz et al., 2011; Dubois et al., 2018).

Ethylene increase, possibly caused by stress caused by herbicide in GR soybean, can weaken cell wall of leaves due to the action of enzymes that degrade cell wall, such as polygalacturonase and cellulase, the latter refers to a hydrolytic enzyme that acts in pectin degradation (Uenojo \& Pastore, 2007) may be responsible for the change, confirmed by the test with ruthenium red.

\section{Conclusion}

The treatment with glyphosate in GR soybean decreased thickness of palisade parenchyma (internervural region) and thickness of the adaxial epidermis, palisade parenchyma, spongy parenchyma and total leaf (midrib region). Although the diameter of the companion cells was reduced with the treatment with the herbicide, the diameter of the metaxylem increased substantially, and this may have led to an increase in the size of the vascular bundle. However, such evidence is indicative of structural changes occurring in response to herbicide.

It is not possible to attribute the answer observed to a stressful condition, since stress not causes permanent damage on growth and grain yield. Therefore, the tolerance gene in fact contributes to the plant not to show indication of stress or herbicide toxicity, restricting the effects to a morphofisiological disorder, that is, a transitory change in some metabolic and/or structural aspect, leading to a response to overcome this adverse condition.

\section{Acknowledgements}

The authors are thankful for the financial support received by the Fundação de Amparo à Pesquisa do Estado de São Paulo (FAPESP-Brazil, grant $\mathrm{N}^{\circ}$. 2012/23266-3) and for the scholarship for scientific initiation (FAPESP-Brazil, grants $\mathrm{N}^{\mathrm{o}}$. 2012/16728-0-NCPB, FAPESP-Brazil, grants $\mathrm{N}^{\circ}$. 2013/23984-6-MSS). No conflict of interest was declared. 


\section{References}

Abu-Irmaileh, B. E., Jordan, L. S., \& Kumamoto, J. (1979). Enhancement of $\mathrm{CO}_{2}$ and ethylene production and cellulase activity by glyphosate in Phaseolus vulgaris. Weed Science, 27(1), 103-106. https://doi.org/ $10.1017 / \mathrm{S} 0043174500043587$

Adams, D. B., \& Adams, W. W. N. (1992). Photoprotection and other responses of plants to high light stress. Annual Reviews Plant Physiology. Plant Molecular Biology, 43(1), 599-626. https://doi.org/10.1146/ annurev.pp.43.060192.003123

Alves, E. S., \& Angyalossy-Alfonso, V. (2000). Ecological trends in the wood of some Brazilian species 1: growth rings and vessels. IAWA Journal, 21(1), 3-30. https://doi.org/10.1163/22941932-90000233

Amaral, L. I. V., Gaspar, M., Costa, P. M. F., Aidar, M. P. M., \& Buckeridge, M. S. (2007). A new rapid and sensitive enzymatic method for extraction and quantification of starch in plant material. Hoehnea, 34, 425-431. https://doi.org/10.1590/S2236-89062007000400001

Appezzato-Da-Glória, B., \& Carmello-Guerreiro, S. M. (2006). Anatomia vegetal (2nd ed.). Viçosa, MG: Editora UFV.

Baas, P. (1982). Systematic, phylogenetic, and ecological wood anatomy-History and perspectives. In P. Baas (Ed.), New Perspectives in Wood Anatomy: Published on the occasion of the 50th Anniversary of the International Association of Wood Anatomists (pp. 23-58). Dordrecht: Springer Netherlands. https://doi.org/ 10.1007/978-94-017-2418-0_2

Baas, P., \& Schweingruber, F. H. (1987). Ecological trends in the wood anatomy of trees, shrubs and climbers from Europe. IAWA Bulletin, 8(3), 245-274. https://doi.org/10.1163/22941932-90001053

Bomfim, N. C. P., Costa, B. G. P., Souza, L. A., Justino, G. C., Aguiar, L. F., \& Camargos, L. S. (2017). Glyphosate effect on nitrogen fixation and metabolization in RR soybean. Journal of Agricultural Science, 9, 114-121. https://doi.org/10.5539/jas.v10n2p157

Carlquist, S. (2001). Comparative wood anatomy: Systematic, ecological and evolutionary aspects of Dicotyledon wood (2nd ed.). Berlin: Springer Verlag.

Casaroli, D., Fangan, E. B., Simon, J., Medeiros, S. P., Manfron, P. A., Durval Neto, P., .. Martin, T. N. (2007). Solar radiation and physiologics aspects in soybean: A review. Revista da Faculdade de Zootecnia, Veterinária e Agronomia, Uruguaiana (FZVA), 14(2), 102-120. Retrieved from http://revistaseletronicas. pucrs.br/ojs/index.php/fzva/article/view/2502/1961

Castle, L. A., Siehl, D. L., Gorton, R., Patten, P. A., Chen, Y. H., Bertain, S., ... Lassner, M. W. (2004). Discovery and Directed Evolution of a Glyphosate Tolerance Gene. Science, 304(5674), 1151-1154. https://doi.org/10.1126/science.1096770

Castro, E. M. D., Pinto, J. E. B. P., Melo, H. C. D., Soares, Â. M., Alvarenga, A. A. D., \& Lima Júnior, É. D. C. (2005). Aspectos anatômicos e fisiológicos de plantas de guaco submetidas a diferentes fotoperíodos. Horticultura Brasileira, 23, 846-850. https://doi.org/10.1590/S0102-05362005000300031

Cerdeira, A. L., Gazziero, D. L. P., Duke, S. O., Matallo, M. B., \& Spadotto, C. A. (2007). Review of potential environmental impacts of transgenic glyphosate-resistant soybean in Brazil. Journal of Environmental Science and Health, Part B, 42(5), 539-549. https://doi.org/10.1080/03601230701391542

CONAB (Companhia Nacional de Abastecimento). (2016). Acompanhamento da Safra Brasileira-Grãos 2015/2016-Décimo Segundo Levantamento. Companhia Nacional de Abastecimento. Retrieved from http://www.conab.gov.br/OlalaCMS/uploads/arquivos/16_09_09_15_18_32_boletim_12_setembro.pdf

De Vos, C. J., \& Swanenburg, M. (2018). Health effects of feeding genetically modified (GM) crops to livestock animals: A review. Food and Chemical Toxicology, 117, 3-12. https://doi.org/10.1016/j.fct.2017.08.031

Digby, J., \& Wareing, P. F. (1966). The Effect of Applied Growth Hormones on Cambial Division and the Differentiation of the Cambial Derivatives. Annals of Botany, 30(3), 539-548. https://doi.org/10.1093/ oxfordjournals.aob.a084095

Dornhoff, G. M., \& Shibles, R. (1976). Leaf morphology and anatomy in relation to $\mathrm{CO}_{2}$-exchange rate of soybean leaves. Crop Science, 16, 377-381. https://doi.org/10.2135/cropsci1976.0011183X001600030015x 
Dubois, M., Claeys, H., Van Den Broeck, L., \& Inzé, D. (2017). Time of day determines Arabidopsis transcriptome and growth dynamics under mild drought. Plant, Cell \& Environment, 40, 180-189. https://doi.org/10.1111/pce.12809

Dubois, M., Van Den Broeck, L., \& Inzé, D. (2018). The Pivotal Role of Ethylene in Plant Growth. Trends in Plant Science, 23, 311-323. https://doi.org/10.1016/j.tplants.2018.01.003

Duke, S. O., Rimando, A. M., Pace, P. F., Reddy, K. N., \& Smeda, R. J. (2003). Isoflavone, glyphosate, and aminomethylphosphonic acid levels in seeds of glyphosate-treated, glyphosate-resistant soybean. Journal of Agricultural and Food Chemistry, 51, 340-344. https://doi.org/10.1021/jf025908i

Durbin, R. D. (1988). The mechanisms for self-protection against bacterial phytotoxins. Annual Review of Phytopathology, 26, 313-329. https://doi.org/10.1146/annurev.py.26.090188.001525

Dvoranen, E. C., Oliveira Jr., R. S., Constantin, J., Cavalieri, S. D., \& Blainski, E. (2008). GR Glycine max nodulation and growth under glyphosate, fluazifop-p-butyl and fomesafen aplication. Planta Daninha, 26, 619-625. https://doi.org/10.1590/S0100-83582008000300018

Fehr, W. R., Caviness, C. F., Burmood, D. T., \& Pennington, J. S. (1971). Stage of development descriptions for soybeans, Glycine $\max$ (L.) Merrill. Crop Science, 11, 929-931. https://doi.org/10.2135/cropsci1971. 0011183X001100060051x

Ferreira, D. F. (2011). Sisvar: A computer statistical analysis system. Ciência e Agrotecnologia (UFLA), 35, 1039-1042. https://doi.org/10.1590/S1413-70542011000600001

Figueiredo, L. A., Silva, D. H., Boaretto, A. E., \& Ribeirinho, V. S. (2011). Efeito do glifosato sobre a fixação de $15 \mathrm{~N}$ em soja transgênica e convencional. Revista Brasileira de Oleaginosas e Fibrosas, 15, $27-36$. Retrieved from https:/ainfo.cnptia.embrapa.br/digital/bitstream/item/50667/1/488-rbof15127-362011.pdf

Fisher, D. B. (1967). An unusual layer of cells in the mesophyll of soybean leaf. Botanical Gazette, 128, $215-218$. Retrieved from https://www.journals.uchicago.edu/doi/abs/10.1086/336403

Franz, J. E, Mao, M. K., \& Sikorski, J. Á. (1997). Glyphosate: A unique global herbicide (1st ed.). Washington, DC: American Chemical Society.

Hoagland, D. R., \& Arnon, D. I. (1950). The water-culture method for growing plants without soil (1st ed.). Berkeley, California: College of Agriculture, University of California.

Hock, S. M., Knezevic, S. Z., Martin, A. R., \& Lindquist, J. L. (2005). Influence of soybean row width and velvetleaf emergence time on velvetleaf (Abutilon theophrasti). Weed Science, 53(2), 160-165. https://doi.org/10.1614/WS-04-122R

ISAAA (International Service for the Acquisition of Agri-biotech Applications). (2016). Global Status of Commercialized Biotech/GM Crops: 2016 (ISAAA Brief, No. 52, p. 125). Ithaca, NY: ISAAA. Retrieved from https:/www.isaaa.org/resources/publications/briefs/52/download/isaaa-brief-52-2016.pdf

Jaworski, E. G. (1972). Mode of action of N-phosphonomethylglycine. Inhibition of aromatic amino acid biosynthsis. Journal of Agricultural and Food Chemistry, 20(6), 1195-1198. https://doi.org/10.1021/ jf60184a057

Jensen, W. A. (1962). Botanical histochemistry (principles and pratice). San Francisco: W. H. Freeman and Company.

Johansen, D. A. (1940). Plant microtechnique. New York: Mc Graw Hill.

Knezevic, S. Z., Evans, S. P., \& Mainz, M. (2003). Row spacing influences the critical timing for weed removal in soybean (Glycine max). Weed Technology, 17, 666-673. https://doi.org/10.1614/WT02-49

Ludwig, M. P., Dutra, L. M. C., Lucca-Filho, A. O., Zabot, L., Jauer, A., \& Uhry, D. (2011). Soybean plant stand in conventional cultivars and Roundup Ready ${ }^{\mathrm{TM}}$. Revista Ceres, 58, 305-313. https://doi.org/10.1590/ S0034-737X2011000300010

Martinez, D. A., Loening, U. E., \& Graham, M. C. (2018). Impacts of glyphosate-based herbicides on disease resistance and health of crops: A review. Environmental Sciences Europe, 30(1), 2. https://doi.org/10.1186/ s12302-018-0131-7

Martins, A. R., \& Appezzato-Da-Gloria, B. (2006). Morfoanatomia dos órgãos vegetativos de Smilax polyantha Griseb (Smilacaceae). Brazilian Journal of Botany, 29, 555-567. https://doi.org/10.1590/S0100-84042006 000400005 
Melo, H. C., De Castro, E. M., Soares, A. M., De Melo, L. A., \& Alves, J. D. (2007). Anatomical and physiological alterations in Setaria anceps Stapf ex Massey and Paspalum paniculatum L. under water deficit conditions. Hoehnea, 34, 145-153. https://doi.org/10.1590/S2236-89062007000200003

Metcalfe, C. R., \& Chalk, L. (1950). Anatomy of the Dicotyledons. Oxford, NY: Clarendon Press.

Padgette, S. R., Re, D. B., Barry, G. F., Eichholtz, D. E., Delannay, X., Fuchs, R. L., \& Fraley, R. T. (1988). New weed control opportunities: Development of glyphosate tolerant soybeans. In S. O. Duke (Ed.), Agricultural, Economic, Environmental, Regulatory, and Technological Aspects (1st ed.). Herbicide-Resistant Crops (pp. 53-84). Boca Raton: CRC Press. https://doi.org/10.1201/9781351073196

Passioura, J. B. (1982). Water in the Soil-Plant-Atmosphere Continuum. In O. L. Lange, P. S. Nobel, C. B. Osmond, \& H. Ziegler (Eds.), Physiological Plant Ecology II: Water Relations and Carbon Assimilation (pp. 5-33). Berlin, Heidelberg: Springer Berlin Heidelberg. https://doi.org/10.1007/978-3-642-68150-9_2

Sakai, W. S. (1973). Simple Method for Differential Staining of Paraffin Embedded Plant Material Using Toluidine Blue O. Stain Technology, 48(5), 247-249. https://doi.org/10.3109/10520297309116632

Sant'Anna-Santos, B. F., Thadeo, M., Meira, R. M. S. A., \& Ascensão, L. (2006). Anatomia e histoquímica das estruturas secretoras do caule de Spondias dulcis Forst. F. (Anacardiaceae). Revista Árvore, 30, 481-489. https://doi.org/10.1590/S0100-67622006000300019

Santos, J. B., Ferreira, E. A., Reis, M. R., Silva, A. A., Fialho, C. M. T., \& Freita, M. A. M. (2007). Avaliação de formulações de glyphosate sobre soja Roundup Ready. Planta Daninha, 25, 165-171. https://doi.org/ $10.1590 / \mathrm{S} 0100-83582007000100018$

Santos, M. C. A., Freitas, S. P., Aroucha, E. M. M., \& Santos, A. L. A. (2009). Anatomia e histoquímica de folhas e raízes de vinca (Catharanthus roseus (L.) G. Don). Revista de Biologia e Ciências da Terra, 9, 24-30. Retrieved from https://www.redalyc.org/pdf/500/50016921004.pdf

Silva, M. S., Oliveira, G. R. F., Lazarini, E., Sá, M. E., Souza, L. A., Justino, G. C., .. Camargos, L. S. (2018). Glyphosate Stimulates the Accumulation of N-Compounds, Grain Yield and Seed Vigor in Glyphosate-Resistant Soybean. Journal of Agricultural Science, 10, 157-166. https://doi.org/10.5539/jas. v10n2p157

Sims, D. A., Seemann, J. R., \& Luo, Y. (1998). Elevated $\mathrm{CO}_{2}$ concentration has independent effects on expansion rates and thickness of soybean leaves across light and nitrogen gradients. Journal of Experimental Botany, 49(320), 583-591. https://doi.org/10.1093/jxb/49.320.583

Skirycz, A., Claeys, H., De Bodt, S., Oikawa, A., Shinoda, S., Andriankaja, M., ... Inzé, D. (2011). Pause-and-Stop: The Effects of Osmotic Stress on Cell Proliferation during Early Leaf Development in Arabidopsis and a Role for Ethylene Signaling in Cell Cycle Arrest. The Plant Cell, 23(5), 1876-1888. https://doi.org/10.1105/tpc. 111.084160

Souto, L. S., \& Oliveira, D. M. T. (2005). Morfoanatomia e ontogênese do fruto e semente de Byrsonima intermedia A. Juss. (Malpighiaceae). Brazilian Journal of Botany, 28, 697-712. https://doi.org/10.1590/ S0100-84042005000400005

Stoyanova, D., Tchakalova, E., \& Yordanov, I. (2002). Influence of different soil moisture on anatomy of maize leaves and ultrastructure of chloroplasts. Journal of Plant Physiology, 28, 11-20. Retrieved from http://www.bio21.bas.bg/ipp/gapbfiles/v-28/02_1-2_11-20.pdf

Strasburger, E. (1913). Handbook of Practical Botany (7th ed.). London: George Allen and Company Ltda.

Thao, N. P., Khan, M. I. R., Thu, N. B. A., Hoang, X. L. T., Asgher, M., Khan, N. A., \& Tran, L.-S. P. (2015). Role of Ethylene and Its Cross Talk with Other Signaling Molecules in Plant Responses to Heavy Metal Stress. Plant Physiology, 169(1), 73-84. https://doi.org/10.1104/pp.15.00663

Tuffi Santos, L. D., Ferreira, F. A., Meira, R. M. S. A., Barros, N. F., Ferreira, L. R., \& Machado, A. F. L. (2005). Leaf growth and morphoanatomy of eucalypt under the effect of glyphosate drift. Planta Daninha, 23, 133-142. https://doi.org/10.1590/S0100-83582005000100016

Tuffi Santos, L. D., Meira, R. M. S. A., Ferreira, F. A., Sant'Anna-Santos, B. F., \& Ferreira, L. R. (2007). Morphological responses of different eucalypt clones submitted to glyphosate drift. Environmental and Experimental Botany, 59(1), 11-20. https://doi.org/ https://doi.org/10.1016/j.envexpbot.2005.09.010 
Tuffi Santos, L. D., Sant'Anna-Santos, B. F., Meira, R. M. S. A., Tiburcio, R. A. S., Ferreira, F. A., Melo, C. A. D., \& Silva, E. F. S. (2008). Visible and anatomic damages caused by glyphosate in Eucalyptus grandis leaves. Planta Daninha, 26, 9-16. https://doi.org/10.1590/S0100-83582008000100002

Tuffi Santos, L. D., Sant'Anna-Santos, B. F., Meira, R. M. S. A., Ferreira, F. A., Tiburcio, R. A. S., \& Machado, A. F. L. (2009). Leaf anatomy and morphometry in the three eucalypt clones treated with glyphosate. Revista Brasileira de Biologia, 69(1), 129-136. https://doi.org/10.1590/S1519-69842009000100016

Uenojo, M., \& Pastore, G. M. (2007). Pectinolytic enzymes. Industrial applications and future perspectives. Química Nova, 30, 388-394. https://doi.org/10.1590/S0100-40422007000200028

USDA (United States Department of Agriculture). (2017). World Agricultural Supply and Demand Estimates. United States Department of Agriculture. Retrieved from https://www.usda.gov/oce/commodity/wasde

Vidal, A., Pognonec, J. C., Claparède, L., \& Meynie, S. (1984). Effet de l'alimentation en eau sur quelques caractères morphologiques et anatomiques des feuilles de soja (Glycine max (L.) Merrill). Agronomie, 4(10), 967-975. https://doi.org/10.1051/agro:19841007

Yamada, T., \& Castro, P. R. R. (2007). Efeitos do glifosato nas plantas: Implicações fisiológicas e agronômicas. Informações Agronômicas, 119, 1-24. Retrieved from https://www.stopogm.net/sites/stopogm.net/files/ webfm/plataforma/EfeitosGlifosatoPlantasImplica\%C3\%A7\%C3\%B5es.pdf

Zablotowicz, R. M., \& Reddy, K. N. (2004). Impact of Glyphosate on the Bradyrhizobium japonicum Symbiosis with Glyphosate-Resistant Transgenic Soybean. Journal of Environmental Quality, 33(3), 825-831. https://doi.org/10.2134/jeq2004.0825

Zeeman, S. C., Smith, S. M., \& Smith, A. M. (2004). The breakdown of starch in leaves. New Phytologist, 163(2), 247-261. https://doi.org/10.1111/j.1469-8137.2004. 01101.x

Zhang, M., Smith, J. A. C., Harberd, N. P., \& Jiang, C. (2016). The regulatory roles of ethylene and reactive oxygen species (ROS) in plant salt stress responses. Plant Molecular Biology, 91(6), 651-659. https://doi.org/10.1007/s11103-016-0488-1

Zobiole, L. H. S., de Oliveira, R. S., Kremer, R. J., Constantin, J., Bonato, C. M., \& Muniz, A. S. (2010). Water use efficiency and photosynthesis of glyphosate-resistant soybean as affected by glyphosate. Pesticide Biochemistry and Physiology, 97(3), 182-193. https://doi.org/10.1016/j.pestbp.2010.01.004

Zobiole, L. H. S., Oliveira Junior, R. S., Constantin, J., \& Biffe, D. F. (2011). Prevention of RR soybean injuries caused by exogenous supply of aminoacids. Planta Daninha, 29, 195-205. https://doi.org/10.1590/ S0100-83582011000100022

\section{Copyrights}

Copyright for this article is retained by the author(s), with first publication rights granted to the journal.

This is an open-access article distributed under the terms and conditions of the Creative Commons Attribution license (http://creativecommons.org/licenses/by/4.0/). 